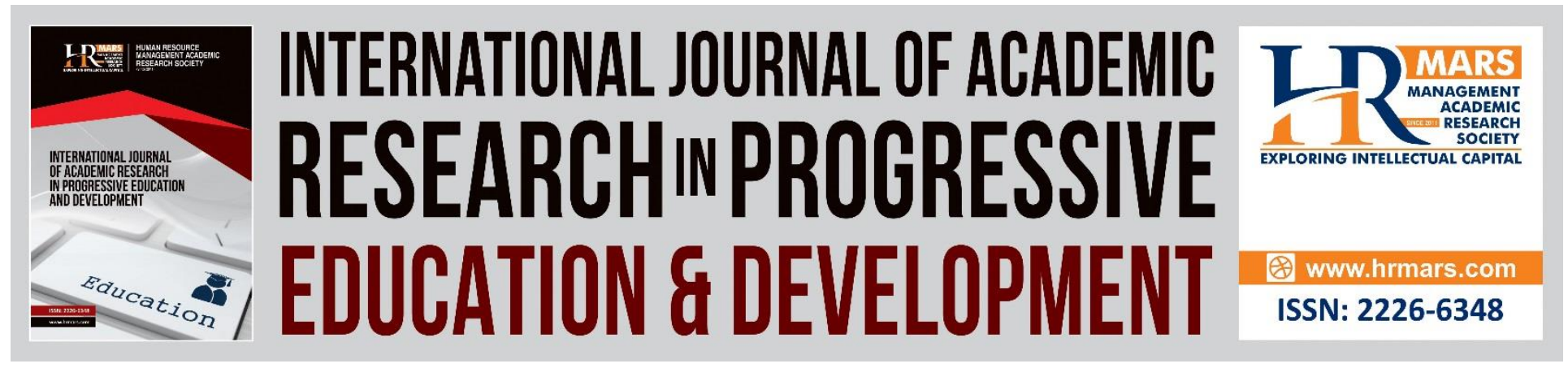

\title{
Utilization of Web 2.0 Applications Among Geography Students at Universiti Pendidikan Sultan Idris, Malaysia
}

Hanifah Mahat, Nurul Izzati Anuar, Saiyidatina Balkhis Norkhaidi, Mohmadisa Hashim, Nasir Nayan \& Yazid Saleh

To Link this Article: http://dx.doi.org/10.6007/IJARPED/v9-i3/8034

DOI:10.6007/IJARPED/v9-i3/8034

Received: 10 July 2020, Revised: 26 July 2020, Accepted: 24 August 2020

Published Online: 27 September 2020

In-Text Citation: (Mahat, et. al., 2020)

To Cite this Article: Mahat, H., Anuar, N. I., Norkhaidi, S. B., Hashim, M., Nayan, N., \& Saleh, Y. (2020). Utilization of Web 2.0 Applications Among Geography Students at Universiti Pendidikan Sultan Idris, Malaysia. International Journal of Academic Research in Progressive Education \& Development. 9(3), 41-54.

Copyright: (c) 2020 The Author(s)

Published by Human Resource Management Academic Research Society (www.hrmars.com)

This article is published under the Creative Commons Attribution (CC BY 4.0) license. Anyone may reproduce, distribute, translate and create derivative works of this article (for both commercial and non-commercial purposes), subject to full attribution to the original publication and authors. The full terms of this license may be seen at: http://creativecommons.org/licences/by/4.0/legalcode

Vol. 9(3) 2020, Pg. 41 - 54

http://hrmars.com/index.php/pages/detail/IJARPED

JOURNAL HOMEPAGE

Full Terms \& Conditions of access and use can be found at http://hrmars.com/index.php/pages/detail/publication-ethics 


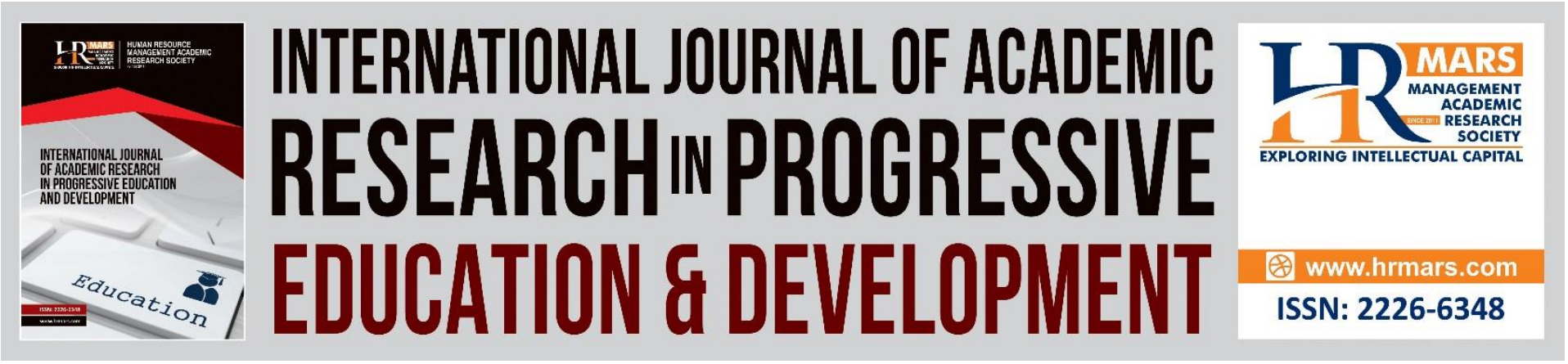

\title{
Utilization of Web 2.0 Applications Among Geography Students at Universiti Pendidikan Sultan Idris, Malaysia
}

\author{
Hanifah Mahat, Nurul Izzati Anuar, Saiyidatina Balkhis Norkhaidi, \\ Mohmadisa Hashim, Nasir Nayan \& Yazid Saleh \\ Department of Geography and Environment, Faculty of Human Science, Universiti Pendidikan \\ Sultan Idris, 35900 Tanjong Malim, Perak. \\ Email: hanifah.mahat@fsk.upsi.edu.my
}

\begin{abstract}
This study aimed to analyze the relationship between usefulness, ease of use and acceptance attitude variables and the utilization of Web 2.0 applications among the geography students of the semester six and seven session of 2019/2020 in Universiti Pendidikan Sultan Idris, Tanjung Malim, Perak, Malaysia. A quantitative approach using a questionnaire was applied in this study. The study samples consisted of 123 geography students ( 42 from semester six and 81 students from semester seven). Sample selection was done using simple random sampling. A descriptive analysis (frequency, percent, mean and standard deviation) and inference analysis (Pearson's correlation) were used to answer each research question. The findings of the study showed that the usefulness $(M=4.29, S D=0.49)$, ease of use $(M=4.21, S D=.48)$, as well as the acceptance attitude towards Web 2.0 applications $(M=4.24$ and $S D=.47)$ were at a high level, while the level of utilization of Web 2.0 applications $(M=3.28$ and $S D=.70)$ was at a medium level. Results from the Pearson's correlation analysis found that there was a positive and significant relationship between Web 2.0 application usefulness $(r=.361, p=.000)$, ease of use $(r=.345, p=.000)$, and attitude $(r=.458, p=.000)$. Regarding the relationship between the independent variables of the study, there were also positive and significant relationships between ease of use and usefulness $(r=.697, p=.000)$ and between usefulness and ease of use or acceptance attitude towards Web 2.0 applications $(r=.624, p=.000$ and $r=.640, p=.000$, respectively). In conclusion, this study showed that the levels of usefulness, ease of use and acceptance attitude towards Web applications among geography students were high but that utilization was medium This indicates that the use of and exposure to Web 2.0 applications at the higher education level are still lacking in the study area. The results of the correlation analysis showed that there was a relationship between all the study variables. Thus, all variables studied should be considered when attempting to increase the utilization of Web 2.0 applications. This information can be used by the Ministry
\end{abstract}


of Education Malaysia, Ministry of Higher Education Malaysia, and the university itself to improve the utilization of Web 2.0 applications to the highest level.

Keywords: Geography Education, Degree Students, Web 2.0 Applications, Usefulness of Applications, Attitude, and Applications.

\section{Introduction}

The Ministry of Education Malaysia (MOE) has made various efforts to encourage the utilization of Web 2.0 applications in teaching and learning (T\&L) by incorporating information technology elements at the core of every educational plan designed, implemented, and formulated (Ministry of Education Malaysia, 2013). The Smart School Project (Projek Sekolah Bestari), Computerization Project (Projek Pengkomputeran), Schoolnet and MySchoolNet Portal have been introduced as part of the Ministry's efforts to empower technology in education (Wan Ali et al., 2009). Therefore, administrators of educational institutions should give serious attention to the internet infrastructure and computer facilities in educational institutions as well as encouraging the utilization of Web 2.0 applications in education so that the planning carried out by the Ministry can be implemented successfully. Attention should also be given to the attitude, knowledge and skills of educators who play a role in realizing the utilization of Web 2.0 applications.

The MOE outlined the utilization of IT to enhance the quality of learning in Malaysia in the seventh shift contained in the Malaysian Development Education Plan 2013-2025 (PPPM 20132015; Ministry of Education Malaysia, 2013). The Ministry of Higher Education Malaysia (MHE) did the same by outlining global online learning goals in the eighth shift (PPPM 2013-2025) to make use of ICT to boost education standards in Malaysia and to make them on par with the world's developed countries. This seventh shift in the MOE and eighth shift in the MHE clearly show that the world today is highly dependent on the advancement of ICT. Web 2.0 technology, for example, is one of the information technologies that is entirely related to IT, and is suitable for use in teaching and learning sessions.

In other countries such as Indonesia, Africa, the United States and Turkey, Web 2.0 technology has been widely used for communication among students and lecturers in some universities. By using a survey-based methodology, Li and Pitts (2009) found that, at a university in Southeast America, Web 2.0 technology had helped to facilitate communication between lecturers and students in a flexible and innovative way. Studies by Augustsson (2010); Churchill (2009); Dzvapatsva et al. (2014); Eyyama et al. (2011) and Soares (2008) also showed that students could use Web 2.0 technology to publish their own writing or results, discuss group assignments and conduct peer reviews of each other's' work.

However, most previous studies did not focus on identifying the extent to which Web 2.0 technology was used in the teaching and learning process among students throughout their university years. This is because most of the previous studies were largely focused on the level of utilization of Web 2.0 technology among teachers at the school level (Jamaludin \& Suzlina Hilwani, 2015; Baharuddin \& Badusah, 2016; Bingimlas, 2017; Capo \& Orellana, 2011) and at other public universities (Abdul Hadi et al., 2016; Aqilah et al., 2012; Hamdan et al., 2015; Abdul Manaf et al., 2015; Mohamad Tanuri et al., 2014). However, few studies have investigated the factors affecting the use of Web 2.0 among students. At Universiti Pendidikan Sultan Idris (UPSI), the current students are from generation $Y$ and generation $Z$ and are familiar with use of the 
Internet and Web 2.0 technology, but the utilization of Web 2.0 applications at the university level has not been determined to date. Therefore, this study aimed to investigate the utilization of Web 2.0 applications among students in the field of Geography at UPSI, examining the level of usefulness, ease of use, student acceptance attitudes and utilization of Web 2.0 applications, and the relationships between these variables.

\section{Internet Technology in the Field of Education}

Since the advent of the Internet, it has become a medium of communication for the public. This is because it provides many opportunities to many people around the world in many ways. Other digital technologies also play a role in everyday life (Dogruer et al., 2011). Broad access to this technology improves people's lives and provides great opportunities, and people can now access information of any kind easily on the Internet and use it for social purposes, education and entertainment. Park (2009) listed the functions of the Internet in education:

i. Communication without boundaries,

ii. Online interactive learning,

iii. Electronic/online research,

iv. Innovation in the new world,

v. Increase interest in learning,

vi. Global education, and

vii. Information catalogue

In education, lecturers, and technology play an important role in students' lives (Rideout et al., 2010). The utilization of technology has changed the daily routine and improved students' critical thinking skills (Fageeh, 2011). Thomas et al. (2015) mentioned that technologies, particularly learning tools, were useful for enhancing students' critical thinking skills. Learning tools are useful in learning and teaching because the tools help retain the attention of students engaged in classroom activities and enhance critical thinking skills (Thomas et al., 2015).

The integration of technological learning tools in the classroom has changed teaching by switching from teacher-centered to student-centered methods (Awaludin et al., 2017). The integration of Internet-based learning tools in the classroom has brought many benefits to students. The findings of Awaludin et al. (2017) supported the findings of DeWitt et al. (2017), who found that the utilization of Padlet helped students to improve their skills, especially through collaboration, interaction, and writing. A study by Henry et al. (2012) showed that students were able to produce longer texts without limiting word characters when using learning tools such as blogger applications. Therefore, it is important to encourage students to use these invaluable resources to get whatever information they need in education as well as to discover their various skills and talents, because Internet development is meaningless if not used properly in education.

\section{The Utilization of Web 2.0 Applications in Education}

Web 2.0 applications have the potential to create an effective teaching and learning environment. Rogers-Estable (2014) suggested that Web 2.0 tools offer opportunities for learning as well as facilitating established relationships and interactions between educators and students, both inside and outside the classroom. This tool helps students to create a group to share, collaborate, 
and improve performance together. Amin et al. (2016) also found that Web 2.0 contributes to knowledge sharing as it facilitates content sharing, collaboration, and communication.

Web 2.0 applications can also increase students' motivation (Karkoulia, 2016). A study conducted by Majid (2014) showed that students' perceptions towards the utilization of Web 2.0 applications were positive. Dumitrescu (2015) found that Web 2.0 integration into classroom learning had helped educators to expand and diversify their teaching and learning approaches, thereby enhancing students' motivation and engagement. Hamdan et al. (2015) found that students were interested in integrating Web 2.0 technology into PdP to achieve meaningful learning. Technology also provides strength in the integration in PdP when all five meaningful learning attributes are successfully achieved.

There are hundreds of Web 2.0 applications that offer the opportunity to interact creatively, and the number continues to grow (Karkoulia, 2016). Web 2.0 applications can be divided into four types, namely as a social networking tool, sharing and creation tool, cloud storage tool and an exercise tool and interactive board. Social networking has become one of the most important communication tools in today's world. Social networking that exists on Internet websites allows millions of people to share their interests in a particular field, and allows members of this social network to share a variety of files, photos and videos, and to create mini blogs and send messages (Wan Hussain \& Fadhilah, 2016). This network is described as social, as these applications enable communication with old and new friends and strengthen relationships between network members on the Internet. Some of the most popular Web 2.0 applications in the world of social networking are Facebook, Twitter, Instagram, WhatsApp, and Telegram (Wan Hussain \& Fadhilah, 2016).

Web 2.0 applications also have the potential to become sharing and creative tools. Such applications allow users to share different types of information as well as create better and innovative products. Indirectly, web applications have encouraged innovative practices among users. Slideshare, Youtube, WordPress, Wiki, Scribd, Flickr and Blogger are examples of Web 2.0 applications that are used to share information and reference materials, and to transform and produce new products. On the other hand, Powtoon, Prezi, Canva and Video Scribd can be used to make presentations or produce something more creative.

Cloud storage is a service that retains data, and remotely manages and backs up data as well as providing data to users via the Internet. There are a significant number of cloud storage providers. Most providers provide space from zero to specific gigabytes. For example, Dropbox provides free space for up to two gigabytes while Google Drive, Box, Amazon, and Apple Cloud provide space from zero to five gigabytes and Microsoft skydrive provides space from zero to seven gigabytes. Clients pay according to a plan once they exceed the specified space limit.

Finally, the interactive features of Web 2.0 technology allow users to actively participate and contribute to the development and expansion of web page content. They allow free online collaboration, social connections, and resource sharing among users. Web 2.0 users are also able to develop, share, and enhance their knowledge and thinking through interactions with other users. An example of a Web 2.0 application that serves as an interactive board is Padlet, while exercise tools include plickers and kahoot. 
DEVELOPMENT

Vol. 9, No. 3, 2020, E-ISSN: 2226-6348 @ 2020 HRMARS

\section{Methodology}

The data in this study were collected using primary data obtained from questionnaires. Simple random sampling was used to select semester six and seven students who were pursuing a Bachelor of Education (Geography) degree (total number 180). Based on Krejcie and Morgan's (1970) sample table, the number of samples to be collected was 123 . The method of primary data collection via questionnaires was conducted online using Google Form.

A pilot study on the study instrument was conducted to determine the reliability of the items constructed based on the following three aspects: usefulness, ease of use and acceptance attitude towards Web 2.0 applications. A total of 30 students from courses other than geography were selected as the pilot study respondents. The pilot study was conducted to determine the questions that needed to be modified, dropped, or retained. The results of the pilot tests in this study showed that the reliability index of each study variable was greater than 0.70 and ranged from Cronbach $a=0.819$ to 0.920 , as recommended by most researchers. The reliability index of this study was thus high.

The two main aims of this study were to examine the levels of usefulness, ease of use, and student acceptance attitudes towards and the utilization of Web 2.0 applications. In addition, this study also analyzed the relationships between these variables. The data for each variable will be presented in the form of percentage value, mean and standard deviation. The levels were based on cut of point setting by Landell's (1997), as follows: low level (score 1.00-2.33), medium level (score 2.34-3.66) and high level (score 3.67-5.00).

\section{Study Findings and Discussion}

This study was conducted at Universiti Pendidikan Sultan Idris. A total of 123 geography students were randomly selected as samples from the 173 geography students in semester six and semester seven (Table 1). There were 89 female respondents $(72.4 \%)$, and 34 male respondents (27.6\%), 41 semester six respondents (33.3\%) and 82 semester seven respondents (66\%). In terms of race, there were 97 Malay (78.9\%), two Chinese (1.6\%), 10 Sarawak Bumiputera (8.1\%) and 14 Sabah Bumiputera (11.4\%).

Table 1. Respondents' Profile

\begin{tabular}{llcc}
\hline Category & Sub Category & Number & Percentage (\%) \\
\hline Semester & Semester 6 & 41 & 33.3 \\
& Semester 7 & 82 & 66.7 \\
& Total & 123 & 100.0 \\
Gender & Male & 34 & \\
& Female & 89 & 27.6 \\
& Total & 123 & $\mathbf{1 0 0 . 0}$ \\
& & & \\
Race & Malay & 97 & 78.9 \\
& Chinese & 2 & 1.6 \\
& Sarawak Bumiputera & 10 & 8.1 \\
& Sabah Bumiputera & 14 & 11.4 \\
& Total & $\mathbf{1 2 3}$ & $\mathbf{1 0 0 . 0}$ \\
\hline
\end{tabular}



Applications

The results of this study are compiled in Table 2 . The findings of the study were analyzed using the mean score, standard deviation, and level of each of the variables and sub-variables involved based on students' assessment. The level analysis comprised the constructs of usefulness of Web 2.0 applications, ease of use of Web 2.0 applications, acceptance attitude towards Web 2.0 applications, and utilization of Web 2.0 applications among geography students in UPSI. Utilization of the Web 2.0 application was the only one with sub-constructs: sharing and creation tool, social networking tool, cloud storage tool and exercise tool and interactive board. The results of the analysis showed that the overall utilization of Web 2.0 applications was high $(M=4.29$ and $\mathrm{SD}=0.49)$, with only 12 students (9.8\%) showing medium utilization, and the remaining 111 students $(90.2 \%)$ showing high utilization. The students believed by using the Web 2.0 tools, students' learning performance could be improved and that the learning content of the Web 2.0 tools was accurate and useful. The utilization of Web 2.0 applications by students could improve the quality of assignments and student productivity. The results of this study are consistent with the findings of studies by Crook et al. (2008); Aqilah et al. (2012) and Abdul Hadi et al. (2016). The findings of this study also support the Technology Acceptance Model (Davis, 1989), which states that the perceived benefits of utilization is one of the key constructs.

The ease of use of Web 2.0 applications among students was also considered high ( $M=4.21$ and $\mathrm{SD}=0.48)$. A total of 109 students $(88.6 \%)$ reported a high level of ease of use while the remaining 14 students (11.4\%) reported a medium level of ease of use of Web 2.0 applications. The findings of the study showed that the students believed that the contents of Web 2.0 applications had enabled them to complete tasks more effectively. They felt that the digital learning content provided by the Web 2.0 tools allowed them to save time accessing information. They also felt that the Web 2.0 applications enhanced interactions, either between teachers and students or between students and students (Ajjan \& Hartshorne, 2008; Liou \& Peng, 2009; dan Yuen et al., 2011) and improved the quality of cooperation between students. The students also thought that the learning and information content was easily accessible on both computers and mobile phones. These findings are in line with studies by Aqilah et al. (2012), Abdul Hadi et al. (2016), and Umbit and Taat (2016), who also found high levels of ease of use when testing technology acceptance among students. The findings of this study also support the Technology Acceptance Model (Davis, 1989), which states that the perceived ease of use is one of the key constructs in the model.

Regarding acceptance attitudes towards Web 2.0 applications, the average level of student acceptance towards Web 2.0 applications was also high ( $M=4.24$ and SD=0.47), with 110 geography students (89.4\%) having high acceptance levels while the other 13 were at a medium level (10.6\%). The findings show that the students liked trying something new, especially in relation to Web 2.0 applications. The students were found to use Web 2.0 applications often for notes and learning materials. The reason for this was because the materials or references generated through Web 2.0 services and applications were clear and dynamic, consisting of blog posts, data mash-ups, ever-changing wiki pages and personal data uploaded to social networking sites (Paul, 2007). The students also found utilizing the Web 2.0 applications fun. This finding is in 
line with past studies by Paraskeva et al. (2008), Aqilah et al. (2012), Ishak (2014), Ermie (2015), and Harmiza (2017), who found that a good or positive attitude towards ICT was an indication of whether or not the new technology would be accepted. Therefore, it can be concluded that the students demonstrated good commitment and high interest in utilizing Web 2.0 applications, especially in the field of education. The findings of this study support the findings of a study conducted by Kürşat (2019), in which respondents showed a positive acceptance attitude towards the utilization of Web 2.0 applications. The high student acceptance attitude towards the utilization of Web 2.0 applications indicates that students are willing to use Web 2.0 applications for the advantages and benefits that can be gained. This findings are also in line with Paraskeva et al. (2008), Roussos (2007) and Ermie (2015), who found that a positive acceptance attitude towards ICT were good predictors of whether students would adopt a new technology or not.

The results of the analysis of the level of Web 2.0 application utilization are presented in Table 4.4. The average level of Web 2.0 application utilization was medium $(\mathrm{M}=3.28$ and $\mathrm{SD}=0.70$ ), with 40 students (32.5\%) reporting a high level of utilization, 72 students (58.5\%) reporting a medium level and the 11 remaining students (8.9\%) reporting a low level. The utilization of Web 2.0 applications by UPSI geography students was evaluated using four subvariables, namely the utilization of Web 2.0 applications as a sharing and creation tool, as a social networking tool, as a cloud storage tool and finally as an exercise tool and interactive board. The average level of utilization of Web 2.0 applications as a sharing and storage tool was medium $(M=3.21$ and $S D=0.84)$, with 38 students (30.9\%) reporting a high level of utilization of Web 2.0 applications as a sharing and creation tool compared to 62 students (50.4\%) who reported a medium level and 23 students (18.7\%) who reported a low level. This indicates that the utilization of Web 2.0 applications as a sharing and creation tool is low, especially for the Flicks and Glogster applications.

The level of utilization of Web 2.0 applications as a social networking tool was medium but with a mean value higher than the utilization of Web 2.0 applications as a sharing and creation tool $(M=3.58$ and $S D=0.78)$. A total of 38 students (39.8\%) reported a high level of utilization of Web 2.0 applications as a social networking tool, while 60 students (48.8\%) reported a medium level and 11 students (11.4\%) reported a low level. This shows that the utilization of Web 2.0 applications as a social networking tool has not yet reached a satisfactory level and that their utilization is not universal. As for the utilization of Web 2.0 applications as a cloud storage tool, the average level of utilization was medium ( $M=3.45$ and $S D=0.90)$. Only 24 students (19.5\%) reported a high level of utilization, while 64 students (52.0\%) reported a medium level and 35 students (28.5\%) reported a low level. Finally, the utilization of Web 2.0 applications as an exercise tool and interactive board was also medium $(M=2.89$ and $S D=0.87)$, with all 123 students $(100 \%)$ reporting a medium level of use. Out of all types of utilization of Web 2.0 applications, use as a training tool and interactive board was the lowest. This tool should therefore be used in every lecture to encourage uptake, and the factors affecting the use of applications should be studied in the future. 
INTERNATIONAL JOURNAL OF ACADEMIC RESEARCH IN PROGRESSIVE EDUCATION AND

DEVELOPMENT

Vol. 9, No. 3, 2020, E-ISSN: $2226-6348$ @ 2020 HRMARS

Table 2. Levels of Usefulness, Ease of Use and Acceptance Attitude towards the Utilization of Web 2.0 Applications

\begin{tabular}{|c|c|c|c|c|c|c|c|c|c|}
\hline \multirow[t]{2}{*}{ Construct } & \multicolumn{2}{|c|}{$\begin{array}{l}\text { Low } \\
\text { Level }\end{array}$} & \multicolumn{2}{|c|}{$\begin{array}{l}\text { Medium } \\
\text { Level }\end{array}$} & \multicolumn{2}{|c|}{ High Level } & \multirow[t]{2}{*}{ Mean } & \multirow[t]{2}{*}{ SD } & \multirow[t]{2}{*}{$\begin{array}{l}\text { Mean } \\
\text { Level }\end{array}$} \\
\hline & $\mathbf{N}$ & $\%$ & $\mathbf{N}$ & $\%$ & $\mathbf{N}$ & $\%$ & & & \\
\hline Usefulness & 0 & 0.0 & 12 & 9.8 & 111 & 90.2 & 4.29 & 0.49 & High \\
\hline Ease of Use & 0 & 0.0 & 14 & 11.4 & 109 & 88.6 & 4.21 & 0.48 & High \\
\hline Acceptance Attitude & 0 & 0.0 & 13 & 10.6 & 110 & 89.4 & 4.24 & 0.47 & High \\
\hline $\begin{array}{l}\text { Utilization of Web } 2.0 \\
\text { Applications }\end{array}$ & 11 & 8.9 & 72 & 58.5 & 40 & 32.5 & 3.28 & 0.70 & Medium \\
\hline $\begin{array}{l}\text { - Sharing and Creation } \\
\text { Tool }\end{array}$ & 23 & 18.7 & 62 & 50.4 & 38 & 30.9 & 3.21 & 0.84 & Medium \\
\hline $\begin{array}{l}\text { - Social Networking } \\
\text { Tool }\end{array}$ & 14 & 11.4 & 60 & 48.8 & 49 & 39.8 & 3.58 & 0.78 & Medium \\
\hline - Cloud Storage Tool & 35 & 28.5 & 64 & 52.0 & 24 & 19.5 & 3.45 & 0.90 & Medium \\
\hline $\begin{array}{l}\text { - Exercise Tool and } \\
\text { Interactive Board }\end{array}$ & 0 & 0 & 123 & 100 & 0 & 0 & 2.89 & 0.87 & Medium \\
\hline
\end{tabular}

Relationships between the Constructs of Usefulness, Ease of Use, and Acceptance Attitude Towards Web 2.0 Applications and Utilization of Web 2.0 Applications among UPSI Geography Students

Pearson's correlation coefficient analysis was used to analyze the relationships between the study variables, as shown in Table 3. The results of this analysis show a strong correlation between the usefulness of Web 2.0 applications and the utilization of Web 2.0 applications ( $r=.361$ ). This indicates a positive relationship with medium strength. The positive sign before the coefficient indicates that the relationship of one variable is proportional to the other variable. The results also show clearly that there is a significant relationship between the Web 2.0 application usefulness variable and Web 2.0 application utilization variable, but that it is very weak with a $p$ value of $p=.000$, which is less than 0.01 . The relationship between the usefulness of an application and the actual use of the application has also been supported by several previous studies (Anisur et al., 2016; Kripanont, 2007; Norzaidi et al., 2007; McFarland \& Hamilton, 2006). This indicates that students are somewhat pragmatic and tend to focus on the uses or benefits of ICT equipment. Therefore, for ICT tools to be accepted by students, it is important for lecturers to show that these tools will help students improve their work performance.

The current study found that ease of use had a significant positive relationship ( $r=.345)$ with the utilization of Web 2.0 applications. The relationship between ease of use and actual utilization of the applications was also demonstrated in previous studies (Anisur et al., 2016; Elkhani et al., 2014; Kripanont, 2007; McFarland \& Hamilton, 2006). The results show that the more students perceive Web 2.0 applications as easy to use and understand, the more Web 2.0 applications will be used. However, this contradicts a study conducted by Lee and Kim (2009), which showed that there was no relationship between ease of use and utilization of the applications. These paradoxical results may indicate that the ease of use of a system or technology may not be enough 
to encourage an individual to utilize the Internet if they are not aware of the usefulness of that system and technology.

Next, the level of acceptance attitude of Web 2.0 applications ( $r=.4 .8$ ) had a positive and significant relationship with the level of Web 2.0 application utilization. This shows that the higher the acceptance attitude of students, the higher the Web 2.0 application utilization was among UPSI geography students. Acceptance attitude is also influenced by the usefulness and ease of use of Web 2.0 applications in the field of education, with higher levels of acceptance associated with perceptions of ease of use and usefulness. Previous studies have revealed similar results (Buabeng-Andoh et al., 2019; Teo et al., 2018).

Table 3. Correlation Analysis of the Usefulness, Ease of Use, and Acceptance Attitude towards the Utilization of Web 2.0 Applications among Students

\begin{tabular}{lcccccc}
\hline Variable & \multicolumn{2}{c}{ Ease of Use } & \multicolumn{2}{c}{ Acceptance Attitude } & \multicolumn{2}{c}{$\begin{array}{c}\text { Utilization of Web } \\
2.0 \text { Applications }\end{array}$} \\
\cline { 2 - 7 } & $\mathrm{r}$ & $\mathrm{p}$ & $\mathrm{r}$ & $\mathrm{p}$ & $\mathrm{r}$ & $\mathrm{p}$ \\
\hline Usefulness & $.697^{* *}$ & .000 & $.624^{* *}$ & .000 & $.361^{* *}$ & .000 \\
Ease of Use & & & $.640^{* *}$ & .000 & $.345^{* *}$ & .000 \\
Acceptance Attitude & & & & & $.458^{* *}$ & .000 \\
\hline
\end{tabular}

\section{Conclusion}

Based on the findings of this study, it can be concluded that the utilization of Web 2.0 applications remains at a moderate and unsatisfactory level among university students, especially geography students. Even though the levels of usefulness, ease of use and acceptance attitude towards Web 2.0 applications among the students were high, they still did not use Web 2.0 applications that much at the university level, especially as an exercise tool and interactive board. Efforts to encourage the utilization of Web 2.0 applications for various functions should be increased so that students can optimize the utilization of Web 2.0 applications in teaching and learning for this technology to be further developed in the field of education. In fact, the development of a national education system that involves Web 2.0 applications should be given more attention. This means that universities need to act to ensure the best utilization of Web 2.0 applications. In addition, research is needed to find the best way to make use of these new tools to enhance teaching and learning activities among the Web 2.0 technology generation.

These change and practice opportunities in Web 2.0 are in line with the discussion in Diffusion of Innovation Theory by Rogers (2003) to predict the use of innovation and the use of systems. In this study, innovation needs to be implemented during the teaching and learning process. Even the Technology Acceptance Model (Davis, 1989) that focuses on the perception of ease of use is proven in this study. The significant relationship between the level of usefulness, ease of use and acceptance of Web 2.0 applications on the use of Web 2.0 applications explains the various functions of innovation through the Web 2.0 should be disseminated so that students and teachers can optimize its use. 
INTERNATIONAL JOURNAL OF ACADEMIC RESEARCH IN PROGRESSIVE EDUCATION AND

DEVELOPMENT

Vol. 9, No. 3, 2020, E-ISSN: $2226-6348$ @ 2020 HRMARS

\section{References}

Abdul Hadi, M. D., Theam, L. S., Palaniandy, M., \& Jamilah, D. (2016). Penerimaan aplikasi Web 2.0 dalam pelaksanaan kurikulum program berasaskan pembelajaran abad ke-21 di Institut Pendidikan Guru. Jurnal Penyelidikan Dedikasi J, 10, 79-97.

Abdul Manaf, S. Z., Din, R., Hamdan, A., Salleh, M. N. S., Kamsin, I. F., \& Abdul Aziz, J. (2015). Penggunaan komputer dan internet Web 2.0 dalam kalangan Generasi Y pelajar universiti. Journal of Advanced Research Design, 7(1), 10-18.

Ajjan, H., \& Hartshorne, R. (2008). Investigating faculty decisions to adopt Web 2.0 technologies: theory and empirical tests. Internet and Higher, 11(2), 71-80.

Amin, N. A. H. N., Hasnan, A. S., Besar, N. N., \& Almunawar, M. N. (2016). Knowledge sharing using Web 2.0: Preferences, benefits, and barriers in Brunei Darusssalam's tertiary education. International Journal of Asian Business and Information Management. 7(4), 1-18.

Anisur, M., Qi, X., \& Islam, T. (2016). Banking access for the poor: Adoption and strategies in rural areas of Bangladesh. Journal of Economic \& Financial Studies, 4(3), 1-10.

Aqilah, A., Tan Bee, H., \& Arshad, H. (2012). Tertiary students' application of Web 2.0 for English language learning. Malaysian Journal of ELT Research, 8(2), 21-37.

Augustsson, G. (2010). Web 2.0 pedagogical support for reflexive and emotional social interaction among Swedish students. Internet and Higher Education, 13, 197-205. Retrieved from http://dx.doi.org/10.1016/j.iheduc.2010.05.005

Awaludin, F. A., Abd Karim, R., \& Saad, M. N. H. (2017). Padlet: A digital collaborative tool for academic writing. Journal of Education and Social Sciences, 8(1), 179-184.

Badusah, J., \& Baharuddin, S. H. (2015). Tahap penggunaan web 2.0 dalam pengajaran guru bahasa melayu sekolah menengah. Jurnal Pendidikan Bahasa Melayu - JPBM (Malay Language Education Journal - MyLEJ), 5(2), 38-48.

Baharuddin, S. H., \& Badusah, J. Suzlina Hilwani, B., \& Jamaludin, B. (2016). Tahap pengetahuan, kemahiran dan sikap guru sekolah menengah terhadap penggunaan Web 2.0 dalam pengajaran Bahasa Melayu. Jurnal Pendidikan Bahasa Melayu - JPBM, 6(2), 33-43.

Bingimlas, K. A. (2017). Learning and teaching with web 2.0 applications in Saudi K-12 Schools. The Turkish Online Journal of Educational Technology, 16(3), 100-115.

Buabeng-Andoh, C. (2018). Predicting students' intention to adopt mobile learning: A combination of theory of reasoned action and technology acceptance model. Journal of Research in Innovative Teaching \& Learning, 11(2), 178-191.

Capo, B. H., \& Orellana, A. (2011). Web 2.0 technologies for classroom instruction: High school teachers' perceptions and adoption factors. The Quarterly Review of Distance Education, 12(305), 235-253.

Church, K., \& De Oliveira, R. (2013, August). What's up with WhatsApp: Comparing mobile instant messaging behaviors with traditional SMS? In Proceedings of the 15th international conference on Human-computer interaction with mobile devices and services, 352-361. ACM.

Churchill, D. (2009). Educational applications of Web 2.0: Using blogs to support teaching and learning. British Journal of Educational Technology, 40(1), 179-183. Retrieved from http://dx.doi.org/10.1111/j.1467-8535.2008.00865.x 
INTERNATIONAL JOURNAL OF ACADEMIC RESEARCH IN PROGRESSIVE EDUCATION AND

DEVELOPMENT

Vol. 9, No. 3, 2020, E-ISSN: $2226-6348$ @ 2020 HRMARS

Crook, C., Cummings, J., Fisher, T., Graber, R., Harrison, C., Lewin, C., Logan, K., Luckin, R., Oliver, M. \& Sharples, M. (2008). Web 2.0 technologies for learning: The current landscape opportunities, challenges, and tensions. Research Report. Retrieved from https://dera.ioe.ac.uk/1474/1/becta_2008_web2_currentlandscape_litrev.pdf

Davis, F. (1989). Perceived usefulness, perceived ease of use, and user acceptance of information technology. MIS Quarterly, 13(2), 319-339.

DeWitt, D., Alias, N., \& Siraj, S. (2017). Collaborative learning: Interactive debates using padlet in a higher education institution. University of Malaya, Malaysia.

Dumitrescu, V. M. (2015). One step ahead: From Web 1.0 to web 2.0 technologies in higher education. Paper presented at the 4th International Scientific Conference: eLearning and Software for Education: eLSE, Bucharest. Romania: CAROLI, National Defence University Publishing House.

Dzvapatsva, G. P., Mitrovic, Z., \& Dietrich, A. D. (2014). Use of social media platforms for improving academic performance at Further Education and Training Colleges. South African. Journal of Information Management, 16(1), 1-11.

Elkhani, N., Soltani, S., \& Ahmad, N. M. (2014). The effects of transformational leadership and ERP system self-efficacy on ERP system usage. Journal of Enterprise Information Management, 27(6), 759-785.

Ermie D. C. D. (2015). Hubungan faktor kebergunaan, kemudahgunaan dan sikap serta kepuasan guru data dan maklumat terhadap EMIS online. (Master Thesis). Fakulti Seni, Komputeran, dan Industri Kreatif Universiti Pendidikan Sultan Idris.

Eyyama, R., Menevi, I., \& Dogruer, N. (2011). Perceptions of teacher candidates towards Web 2.0 technologies. Procedia Social and Behavioural Sciences 15(5), 2663-2666.

Fageeh, A. I. (2011). EFL learners' use of blogging for developing writing skills and enhancing attitudes towards english learning: An exploratory study. Journal of Language and Literature, 2(1), 31-48

Hamdan, A., Din, R., Abdul Manaf, S. Z., Mat Salleh, N. S., Kamsin, I. F., Norman, H., Ismail, N. M., Mohamad Zaid, A. S. (2015). Pengintegrasian Teknologi Web 2.0 dalam Mencapai Pembelajaran Bermakna. Sains Humanika, 1(2012), 51-59.

Hamdan, A., Din, R., Adnan, A., Abdul Manaf, S. Z., Ismail, N. M., Mat Salleh, N. S., \& Shafiin, H. (2013). Penggunaan teknologi Web 2.0 dalam pembelajaran hibrid. Tempawan Jurnal Penyelidikan, 1, 87-103.

Harmiza, I. (2017). Hubungan antara penerimaan dengan sikap terhadap penggunaan sistem pengurusan pembelajaran maya. (Master Thesis). Universiti Pendidikan Sultan Idris.

Henry, L., Castek, J., \& Zawilinski, L. (2012). Using peer collaboration to support online reading, writing and communication: An empowerment model for struggling readers. Reading and Writing Quarterly. 28, 279-306.

Ishak, M. S. (2014). Pemodelan penerimagunaan maklumat berkaitan Islam di internet: pengaplikasian model penerimaan teknologi (TAM). Journal of Techno Social, 6(2), 49-61.

Karkoulia, K. C. (2016). Teachers' attitudes towards the integration of Web 2.0 tools in EFL teaching. Research Papers in Language Teaching and Learning, 1(7), 46-73.

Kementerian Pendidikan Malaysia (KPM). (2013). Pelan Pembangunan Pendidikan Malaysia 20132025. Putrajaya: Bahagian Pembangunan Kurikulum. 
INTERNATIONAL JOURNAL OF ACADEMIC RESEARCH IN PROGRESSIVE EDUCATION AND

DEVELOPMENT

Vol. 9, No. 3, 2020, E-ISSN: 2226-6348 @ 2020 HRMARS

Kementerian Pendidikan Malaysia (KPM). (2015). Pelan Pembangunan Pendidikan Malaysia 20152025 (Pendidikan Tinggi), 1-12.

Kripanont, N. (2007). Examining a technology acceptance model of internet usage by academics within thai business schools. (Master Thesis). Faculty of Business and Law, Victoria University

Landell, K. (1997). Management by menu. London: Wiley and Sons Inc.

Lee, S., \& Kim, B. G. (2009). Factors affecting the usage of intranet: A confirmatory study. Computers in Human Behavior, 25(1), 191-201.

Li, L., \& Pitts, J. P. (2009). Does it really matter? Using virtual office hours to enhance studentfaculty interaction. Journal of Information Systems Education, 20(2), 175-185.

Liou, H. C., \& Peng, Z. (2009). Training effects on computer-mediated peer review. System, 37(3), 514-525.

Majid, N. N. (2014). Integration of web 2.0 tools in learning a programming course. TOJET,

McFarland, D. J., \& Hamilton, D. (2006). Adding contextual specificity to the technology acceptance model. Computers in Human Behavior, 22(3), 427-447.

Tanuri, M. Z. A., Azmi, N. A., \& Sawal, M. Z. H. (2014). Web 2.0 tools in facilitating the construction of knowledge in higher education. Esteem Academic Journal, 10(2), 1-9.

Norzaidi, M. D., Chong, S. C., Murali, R., \& Salwani, M. I. (2007). Intranet usage and managers' performance in the port industry. Industrial Management \& Data Systems, 107(8), 12271250.

Paraskeva, F., Bouta, H., \& Aik, P. (2008). Individual characteristics and computer self-efficacy in secondary education teachers to integrate technology in educational practice. Computers \& Education, 50(2), 1084-1091

Park, H. W. (2009). Academic internet use: Issues and lessons in e-research. a paper presented to the communication and technology division, the 59th Annual ICA (International Communication Association) Conference, Chicago, Illinois USA (Chicago Marriott Downtown Magnificent Mile, May 21-25, 2009).

Paul, A. (2007). What is Web 2.0? Ideas, technologies, and implications for education. JISC Technology and Standards Watch.

Rideout, V., Foehr, U., \& Roberts, D. (2010). Generation M2: Media in the Lives of 8- to 18- yearolds. A Kaiser Family Foundation Study, 1-72.

Rogers E. M. (2003). Diffusion of innovation. 5th ed. New York, NY: Free Press

Rogers-Estable, M. (2014). Web 2.0 use in higher education. European Journal of Open, Distance and elearning,17(2):129-141.

Roussos, P. (2007). The Greek computer attitudes scale: construction and assessment of psychometric properties. Computers in Human Behavior, 23, (1), 578-590.

Soares, D. A. (2008). Understanding class blogs as a tool for language development. Language Teaching Research 12(4), 517-533.

Teo, T. S., Lim, V. K., \& Lai, R. Y. (1999). Intrinsic and extrinsic motivation in Internet usage. Omega, 1(1), 25-37.

The Turkish Online Journal of Educational Technology, 4(13), 88-94. 
Thomas, J. D. E., Morin, D., \& Ly, S. (2014). Delivery method and persistence and performance. In Proceedings of World Conference on Educational Multimedia, Hypermedia and Telecommunications, Tampere, Finland, 1797-1801.

Umbit, A., \& Taat, M. S. (2016). Faktor-faktor yang mempengaruhi penerimaan e-pembelajaran dalam kalangan pelajar di institut. Jurnal Penyelidikan IPGK BL, 13, 1-14.

Wan Ali, W. Z., Said Husain, S. K., Ismail, M. R., Ismail, H., Tarmizi, A. R., Hamzah, R., \& Konting, M. M. (2009). Amalan penerapan nilai matematik dalam bilik darjah. In Ahmad Fauzi Mohd Ayub \& Aida Suraya Md. Yunus. Pendidikan Matematik \& Aplikasi Teknologi, 33-66. Selangor, Malaysia: Universiti Putra Malaysia.

Wan Hussain, W. I., \& Fadhilah, M. Y. (2016). Kesan pembelajaran elektronik ke atas kemahiran ICT pelajar. E Proceeding National Innovation and Invention Competition Through Exhibition (ICompEx'17).

Yuen, S. C. Y., Yaoyuneyong, G., \& Yuen, P. (2011). Perceptions, interest, and use: teachers and Web 2.0 tools in education. International Journal of Technology in Teaching and Learning, 7(2), 109-123. 